\title{
A presença da literatura brasileira na formação dos sistemas literários dos paises africanos de lingua portuguesa
}

Tania Macêdo ${ }^{1}$

Sou um angolano capaz de sentir o Brasil, capaz de recitar de cor um poema de Manuel Bandeira, capaz de sambar com intenção ao som de uma marchinha de Luiz Gonzaga, ouvindo o bater ritmado dum tambor com acompanhamento de recoreco.

Ernesto Lara Filho

Eu gosto de Você, Brasil, porque Você é parecido com a minha terra. Eu bem sei que Você é um mundão e que a minha terra são dez ilhas perdidas no Atlântico,sem nenhuma importância no mapa. (...)

(...)

Eu gostava enfim de o conhecer mais de perto e Você veria como sou um bom camarada. Havia então de botar uma fala ao poeta Manuel Bandeira,de fazer uma consulta ao Dr. Jorge de Lima para ver como é que a Poesia receitava este meu figado tropical bastante cansado. Havia de falar como Você, com um i no si "si faz favor", de trocar sempre os pronomes para antes dos verbos "mi dá um cigarro?"

1 Professora Titular da Área de Estudos Comparados de Literaturas de Língua Portuguesa, da FFCHL/USP. 
Mas tudo isso são cousas impossiveis Você sabe? - Impossiveis

Jorge Barbosa - "Você Brasil" dedicado a Ribeiro Couto

$O$ cais...

O cais é um cais como muitos cais do mundo...

As estrelas também são iguais

às que se acendem nas noites baianas

de mistério e macumba...

(Que importa, afinal, que as gentes sejam moçambicanas ou brasileiras, brancas ou negras?)

Jorge Amado, vem!

Aqui, nesta povoação africana

o povo é o mesmo também

é irmão do povo marinheiro da Baía, companheiro Jorge Amado,

amigo do povo, da justiça e da liberdade!

Noemia de Sousa - Poema a Jorge Amado

Antes de iniciar, creio que é interessante lembrar aqui um artigo de $1970^{2}$, de Czeslau Milosz em que o autor rebate de forma bastante irônica os questionamentos de resenhistas sobre o livro que ele publicara no ano anterior, História da literatura polonesa (The History of Polish Literature). No artigo Milosz diz que as questões atinentes ao método acabaram por conduzir a historiografia literária de nosso tempo ao penoso estado de uma centopéia neurastênica, ou seja, de tanto refletir sobre qual perna mexer primeiro, ela acaba não podendo sair do lugar.

Pretendendo que este trabalho, de alguma maneira, caminhe pela história literária de três dos países africanos de língua portuguesa, as

2 Milosz, Czeslaw. "O historii polskiej literatury, wolnomyslicielach i masonach", texto mais tarde incluído no volume Prywatne obowiazki. Olsztyn: Pojezierze, 1990. In SOUZA, Marcelo Paiva de. Especulo. Madri, Revista digital, n 31, nov 2005, fev. 2006. 
questões relativas à metodologia se farão presentes. Não serão elas, todavia, as predominantes.

Comecemos, pois, indicando que iluminar a questão da formação dos jovens sistemas literários dos países africanos de língua portuguesa é também exibir os contornos de bem- sucedidos projetos de estabelecimento de modernidade literária em Angola, Cabo Verde e Moçambique, assim como lançar luzes sobre o contexto violento em que foram engendrados aqueles sistemas.

Trata-se, pois, de examinar, na senda do que propôs João Luís Lafetá ao abordar o modernismo brasileiro de 1930, as novas proposições estéticas apresentadas pelos sistemas literários dos países africanos de lingua portuguesa em suas

duas faces (complementares e, aliás, intimamente conjugadas; não obstante, às vezes relacionadas em forte tensão): enquanto projeto estético, diretamente ligada às modificações operadas na linguagem, e enquanto projeto ideológico, diretamente atada ao pensamento (visão de mundo) de sua época. (CANDIDO, apud LAFETÁ, 2000, p. 9)

E, dessa maneira, verificar em que medida a crítica a uma linguagem literária realizada por jovens autores africanos a partir dos fins dos anos 1930 constituiu uma face de um projeto ideológico.

A partir desta perspectiva, o papel exercido pela literatura brasileira no processo de formação dos sistemas literários dos países africanos de lingua portuguesa deve ser examinado de forma a pôr em relevo as tensões, escolhas e projetos que recobrem questões como a do sistema de produção colonial, as relações ali engendradas e a da literatura nacional.

Antes, entretanto, de focalizar a consolidação dos sistemas literários dos países africanos, examinemos, mesmo que de maneira breve, algumas "manifestações literárias" que dialogaram com a literatura brasileira, a fim de que possamos problematizar mais de perto a questão da tradição literária sob o colonialismo. Como se recorda, Antonio Candido, no seminal Formação da literatura brasileira, que 
referir-se-á às manifestações literárias como descontínuas e dispersas, não conseguindo estabelecer uma tradição.

Ocorre que sob o sistema colonial a tradição é fraturada, na medida em que na lógica colonial a existência de um sistema literário autônomo, do colonizado, significaria tanto uma maneira própria de representação de si e do outro, a negação dos modelos tecnoformais da literatura das metrópoles mas, principalmente, a negação do domínio colonial. Nesse sentido, a formação dos sistemas literários dos países africanos de língua portuguesa articular-se-á, necessariamente ao projeto de nação ou, nas palavras de Memmi,

A emergência de uma literatura de colonizados, a tomada de consciência de escritores norte-africanos, por exemplo, não é um fenômeno isolado. Participa da tomada de consciência de si mesmo de todo um grupo humano. O fruto não é um acidente ou um milagre da planta, mas o sinal de sua maturidade. (MEMMI, 1977, p. 99)

\section{RELACIONANDO}

Examinada em perspectiva histórica, a proximidade entre textos e produtores literários do Brasil (ou a ele identificado) e os dos países africanos de língua portuguesa remonta ao século XVIII na medida em que autores como Gregório de Matos Guerra e Tomás Antonio Gonzaga, degredados para terras africanas, lá produziram textos e, segundo esparsas informações documentais que hoje possuímos, acabaram por incentivar os insipientes grupos de escritores ali presentes.

É de se referir, entretanto, que os textos de que dispomos e que foram produzidos por aqueles dois autores em terras africanas, remetem a uma imagem bastante adversa e/ou distante do continente africano, na medida em que assumem uma visão metropolitana. Apenas para exemplificar o que afirmamos, citemos dois poemas.

O primeiro deles, de Tomás Antonio Gonzaga, que se refere a seu exílio: 
OS AFRICANOS PEITOS CARIDOSOS

A Moçambique aqui vim deportado.

Descoberta a cabeça ao sol ardente;

Trouxe por irrisão duro castigo

Ante a africana, pia, boa gente.

Graças, Alcino amigo,

Graças à nossa estrela!

Não esmolei, aqui não se mendiga;

Os africanos peitos caridosos

Antes que a mão infeliz lhe estenda,

A socorrê-lo correm pressurosos.

Graças, Alcino amigo,

Graças à nossa estrela!

Aqui vale a pena pensar quem são os africanos a que o poema com forte pendor autobiográfico se refere, na medida em que como se sabe, o poeta em Moçambique tinha "próprio casal e nele assistia" (para lembrar outros versos de Gonzaga) em um quadro em que a economia existia graças ao tráfico de escravos...

Quanto a Gregório de Matos, os versos sarcásticos e mordazes que o teriam levado a Angola, também ali no desterro se fizeram presentes, na medida em que a negação das terras e gentes de Angola são explorados em

LAMENTA O POETA O TRISTE PARADEYRO DA SUA FORTUNA DESCREVENDO AS MIZERIAS DO REYNO DE ANGOLLA PARA ONDE O DESTERRARAM.

Nesta turbulenta terra

armazém de pena, e dor,

confusa mais do temor,

inferno em vida. 
Terra de gente oprimida, monturo de Portugal,

para onde purga seu mal, e sua escória:

Onde se tem por vanglória

o furto, a malignidade,

a mentira, a falsidade,

e o interesse:

Onde a justiça perece

por falta, de quem a entenda,

e onde para haver emenda

usa Deus,

Do que usava cos Judeus, quando era Deus de vinganças, que com todas as três lanças

de sua ira

De seu tronco nos atira

com peste, e sanguínea guerra,

com infecúndias da terra,

e pestilente

Febre maligna, e ardente, que aos três dias, ou aos sete

debaixo da terra mete

o mais robusto.

(..)

Deste nosso respirar

efeitos da zona ardente, onde a etiópica gente

faz morada:

Gente asnaval, e tostada, que da cor da escura noite

a pura marca, e açoite

se encaminha:

Aqui a fortuna minha

conjurada com seu fado 


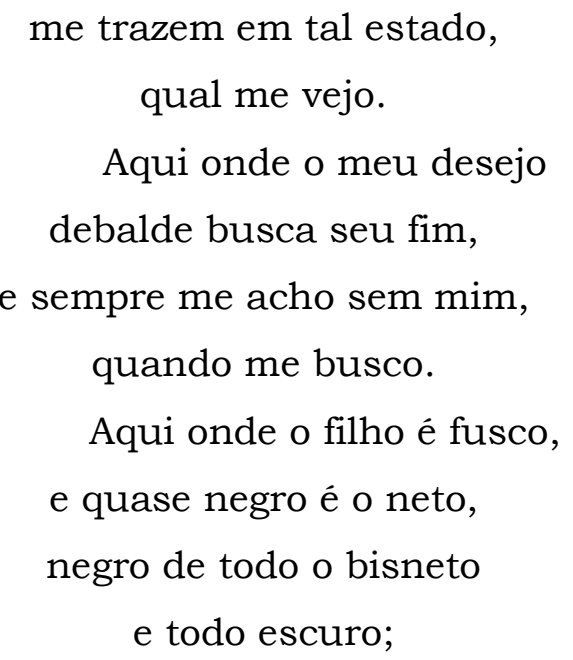

Gregório de Matos não economiza nas tintas para pintar um quadro detestável de Angola, estabelecendo-a como armazém de dor em que pagam as penas os degredados ("Terra de gente oprimida,/monturo de Portugal,/para onde purga seu mal,/e sua escória"), e onde os negros, "gente asnaval", só se conduz mediante açoites. É uma visão do inferno que emerge do poema e que durante muito tempo selaria as imagens de Angola no imaginário colonial.

Os dois exemplos demonstram o quanto o olhar dos nossos produtores letrados, na mesma senda de nossa elite colonial, mira com menosprezo os africanos, identificados ao trabalho mecânico e manual e, portanto, desprezível a dois lídimos representantes da "ética do aventureiro" estudada por Sérgio Buarque de Holanda ${ }^{3}$.

Regidas, assim, pela lógica colonial, as primeiras aproximações entre autores da literatura produzida no Brasil e Angola não foram as mais amistosas...

Já no século XIX forjam-se mecanismos de maior aproximação literária entre os países africanos e a literatura brasileira, como se pode inferir, por exemplo, da publicação Almanach de Lembranças Luso-

\footnotetext{
${ }^{3}$ Lembre-se que a partir dos conceitos de "trabalho e aventura", Sérgio Buarque de Holanda distingue o trabalhador e o aventureiro e apresenta como traço diferencial da colonização portuguesa, a "ética do aventureiro", que se caracterizava pela audácia, imprevidência, irresponsabilidade, instabilidade e indolência: "Na obra da conquista e colonização dos novos mundos, coube ao trabalhador papel muito limitado, quase nulo" (p.56).
} 
brasileiro (1851-1900 - primeira fase) que se constitui em importante veículo de diálogo literário, já que, em função de sua longevidade e do elevado número de colaboradores (e assinantes) estabelece um espaço de conhecimento de várias realidades e textos. Dessa forma, vemos cruzarem-se nas páginas dos pequeninos livros cheios de informações úteis, jovens escritores como os brasileiros Casimiro de Abreu e Machado de Assis, os angolanos Cordeiro da Mata e José da Silva Maia Ferreira, assim como os caboverdianos José Lopes da Silva e Maria Luisa de Sena Barcelos, ou ainda o moçambicano Campos Oliveira, para citarmos alguns nomes mais importantes.

Trata-se de uma experiência interessante, na medida em que essa publicação, importante veículo de divulgação de textos, chegava a um amplo público no Brasil, nos países africanos de língua portuguesa e em Portugal, propiciando que autores e público em geral conhecessem os poemas e pequenas narrativas escritos nos três continentes.

No mesmo Almanach, em 1883, foram publicados versos de Caetano Costa Alegre, um dos primeiros poetas negros são-tomenses, cuja poesia foi atravessada por referências ao preconceito racial como se depreende em "Aurora"4: "És a luz, eu a sombra pavorosa". Dada a questão racial que percorre os textos de Costa Alegre, não causa espanto que o diálogo com Castro Alves se realize em um de seus poemas. Trata-se de uma pequena citação de Navio Negreiro (1869) (Primeira estrofe da Parte IV). Como se recorda, essa estrofe do autor brasileiro diz: "Era um sonho dantesco... o tombadilho/ Que das luzernas avermelha o brilho./Em sangue a se banhar./ Tinir de ferros... estalar de açoite.../ Legiões de homens negros como a noite,/ Horrendos a dançar...). No soneto de Costa Alegre, o clima tornar-se quase aprazivel, já que a música de ferros e açoites descrita pelo autor brasileiro transforma-se em um canto entoado por uma "gentil morena: "Era um sonho dantesco"... repetia/Aquela pálida e gentil morena,/Na fresca e doce entoação amena/do canto de ave ao

${ }^{4}$ Do livro Versos, publicado postumamente em 1916, mas escrito em Lisboa por volta de 1884. 
despontar do dia.// "Era um sonho dantesco"... ela dizia,/Poisando a fronte cândida e serena/ $\mathrm{Na}$ branca mão artística e pequena/Imaginando o sonho que seria".

Por último, ainda no terreno das manifestações literárias, vale lembrar que em 1850 é publicado o primeiro livro de poesia na África Austral, o Espontaneidades da minha alma: Às senhoras africanas (1850), de José da Silva Maia Ferreira, que traz a experiência desse luandense ${ }^{5}$ que viera estudar no Brasil (1834-1845) e aqui acabou por manter contato com a poesia de românticos brasileiros, como se nota, por exemplo, no poema "À saudade", que tem por epígrafe uma estrofe de "Queixume" (Segundos cantos), de Gonçalves Dias, ou o poema "À minha terra" (No momento de avistá-la depois de uma viagem), que dialoga muito de perto com a "Canção do exílio" do mesmo Gonçalves Dias:

De leite e mar - lá desponta

Entre as vagas sussurrando

A terra em que cismando

Vejo ao longe branquejar!

É baça e proeminente,

Tem da África o sol ardente,

Que sobre a areia fervente

Vem-me a mente acalentar.

Debaixo do fogo intenso,

Onde só brilha formosa,

Sinto na alma fervorosa

O desejo de a abraçar:

É minha terra querida,

Toda da alma, - toda-vida, -

Que entre gozos foi fruídas

Sem temores, nem pesar.

Bendita sejas, ó terra,

Minha terra primorosa,

Despe as galas - que vaidosa

Ante mim queres mostrar:

Mesmo simples tens fulgores,

Os teus montes têm primores,

\footnotetext{
5 Ainda que alguns estudiosos indiquem como local de nascimento do poeta a cidade de Benguela., Carlos Pacheco com seus estudos dirimiu qualquer dúvida quando a Maia Ferreira ser luandense. A respeito, ver PACHECO, Carlos. José da Silva Maia Ferreira. Novas achegas para a sua biografia. Luanda: União dos escritores angolanos, 1992.
} 
Que às vezes falam de amores

A quem os sabe adorar!

Navega pois, meu madeiro, Nestas águas de esmeraldas, Vai junto do monte às faldas

Nessas praias a brilhar!

Vai mirar a natureza,

Da minha terra a beleza,

Que é singela, e sem fereza

Nesses plainos de além-mar

Da leite o mar, - eis desponta

Lá na estrema do horizonte,

Entre as vagas - alto monte

Da minha terra natal;

É pobre, - mas tão formosa

Em alcantis primorosa,

Quando brilha radiosa,

No mundo não tem igual!

(MAIA FERREIRA, 1985, p. 101-102)

Como se nota, Angola, no poema de Maia Ferreira, recebe as mesmas tintas de "primores" e "fulgores", do quadro ufanista pintado pelos nossos românticos quando se referem ao Brasil e, dessa maneira, pode-se identificar uma convergência entre o poema do autor angolano e a maioria dos textos daquela quadra produzidos no Brasil, o que nos remete às reflexões de Antonio Candido, para quem essa é uma "literatura que compensava o atraso material e a debilidade das instituições por meio da supervalorização dos aspectos regionais", com uma "linguagem de celebração e terno apego, favorecida pelo Romantismo, com apoio na hipérbole e na transformação do exotismo em estado de alma" (CANDIDO, 1989, p. 141). No poema citado, a simplicidade e aparente pobreza da terra são amplamente compensadas pelo seu brilho radioso e beleza incomparável, que indicam, por um lado, um apego à terra sinônimo, neste caso, de nativismo; mas, por outro, opera-se um apagamento das dificuldades e contradições, na medida em que a situação colonial é obliterada e, destarte, há, para usar as palavras de Candido, "uma consciência amena do atraso". 
Se retomarmos três dos quatro poemas até aqui apresentados e examinarmos as descrições e as imagens homólogas (sobretudo o "sol ardente" e o "calor'), metonímias do continente africano, percebe-se uma mudança importante, na medida em que no texto de Gregório de Matos o calor engendra a "Febre maligna, e ardente" assim como remete à gente "asnaval" e tostada. Passado um século, Gonzaga também referir-se-á ao sol como castigo. No entanto, Maia Ferreira elabora de forma diversa essas imagens, na medida em que o sol é brilhante e incide nas águas do mar tornando-as esmeraldas, assim como permite que a terra natal, em brasa, contamine o poeta que sente a alma fervorosa e, a partir disso, estabelece com ela uma relação quase erótica que se despe para o poeta Maia Ferreira que a quer abraçar.

Trata-se, como se pode aquilatar, de diferenças importantes, que indiciam relações diversas do sujeito com a terra e uma relação de pertença - o nativismo - que, mesmo brevemente vale a pena examinar.

A respeito do nativismo nos países africanos de lingua portuguesa, vale lembrar que alguns autores, dentre os quais se destaca Mário Pinto de Andrade, apontam o século XIX como marco incontornável, na medida em que nesse momento teriam ocorrido as "primeiras interpretações do poder colonial na base das reivindicações locais e expressões incipientes de uma identidade cultural não isenta de ambigüidades" (ANDRADE, 1998, p. 53). É por essa altura que uma elite letrada das colônias expressa suas reivindicações sobretudo por intermédio do periodismo, que se tornou não apenas o canal de divulgação das demandas, mas também a expressão de suas ambigüidades. A respeito, veja-se a definição de nativismo, de autoria de Eugenio Tavares estampada no jornal A voz de Cabo Verde:

Eis o nativismo:

A dor de perder os filhos, músculo do nosso peito; a suprema paixão de ver insultada a nossa alma que, mesmo reside em nós que nos lábios que beijamos com amor (...) incontrovertivelmente: nunca saberá amar a sua pátria aquele que não soube ou não pode amar a sua 
região, a sua aldeia, o seu homem, sua mulher, seus filhos" (apud ANDRADE, 1988, p. 111)

De um cariz bastante intimo, a definição acima poderia nos conduzir a erro sobre o perfil do seu autor, não fora a sua atuação que visava à independência, como nos aponta Alfredo Margarido:

Se bem que timidamente, os jovens intelectuais caboverdianos dos finais do século XIX não hesitam em pronunciar-se pela necessidade da independência, como se verifica na Revista de Cabo Verde, replicando desta maneira aos projectos de venda das colônias que se manifestavam no espaço colonial português e que só se extinguiram com a Ditadura militar de 1926. No plano estético, mas sobretudo no plano teórico, avultam as intervenções de Eugenio Tavares e de Pedro Monteiro Cardoso, possuindo o primeiro uma experiência, e cabendo ao segundo a utilização dos valores africanos exaltados pelos pan-africanistas, como Egito e Cartago. (MARGARIDO, 2002, p. 56)

Alguns anos depois, no início do século XX, uma posição mais incisiva, situando a questão do nativismo e do nacionalismo encontrarse-ia no jornal $O$ emancipador, publicado em Lourenço Marques (hoje Maputo):

... Não façam nativismo. Façam socialismo. Não dêem aos pretos a noção de que a África pertence aos africanos. Dêem-lhes a noção de que a África pertence à Humanidade. Não os aconselhem a combater os brancos por causa da diferença de raça. Ensinem-lhes a combater os exploradores: brancos, amarelos, pardos e da sua própria raça... não tornem os pretos livres num país graças à lei da pátria, deixando-os escravos amarrados à lei do salário. (apud ANDRADE, 1998, p. 113)

Aparentemente o texto é bastante progressista ao expor as contradições do nativismo, contrastando-o com o socialismo: aquele restrito a uma questão racial, este atinente à Humanidade; aquele travando um combate circunscrito aos brancos, este lutando contra os exploradores de todas as cores. Se o leitor tem o impulso de aderir ao discurso, no primeiro momento, o tom algo impositivo do texto ("não 
façam" ("façam") estabelece alguma desconfiança, na medida em que o emissor do discurso coloca-se em uma posição de saber superior ao receptor - os africanos, e em que a luta anticolonial é minimizada pela luta de classes.

Saber que $O$ emancipador, jornal que estampou o texto, foi editado em Lourenço Marques no início do século XX por um grupo de operários... portugueses, aprofunda a dúvida. O periódico integrava uma imprensa operária aguerrida que floresceu em Moçambique nos primeiros anos do século XX e da qual participavam, entre outros, os jornais $O$ Germinal e Os simples.

Focalizado em uma perspectiva mais ampla, nota-se que está em pauta muito mais que o tom do texto, já que no pequeno trecho citado esgueira-se a contradição dos partidos de esquerda europeus no século passado no que concerne ao nacionalismo dos movimentos anticoloniais: se por um lado apóia-se a luta contra o colonialismo, de outro condena-se - como aqui - o nativismo em nome do socialismo, em razão de uma incompreensão da reivindicação nacional.

Vale aqui lembrar como, de forma perspicaz, Memmi em Retrato do colonizado precedido pelo retrato do colonizador, de 1957, refere-se à equivocada percepção da esquerda européia a respeito do nacionalismo:

Existe um incontestável mal-estar da esquerda européia em face do nacionalismo. O socialismo pretendeu ter vocação internacionalista durante tanto tempo que essa tradição pareceu ligar-se definitivamente à sua doutrina, e incluir-se entre os seus principios fundamentais (...)

Ora, por múltiplas razões históricas, sociológicas e psicológicas, a luta dos colonizados pela sua libertação assumiu acentuado aspecto nacional e nacionalista. Se a esquerda européia não pode senão aprovar, encorajar e sustentar esta luta, como toda e qualquer esperança de liberdade, sente profunda hesitação, real inquietação diante da forma nacionalista dessas tentativas de libertação. (MEMMI, 1977, p. 40,41)

No caso de Portugal - e mais especificamente do PCP (Partido Comunista Português), o equívoco se perpetuou, na medida em que apenas no seu V Congresso, em 1957, o Partido se manifestaria de 
forma inequívoca contra o jugo colonial português, ao afirmar "o direito à independência imediata e sem condições das colónias da África Portuguesa" ( in.: Lisboa: Avante, 1957).

Não se pode deixar à margem que o chamado "nacionalismo africano" consistiu em uma resposta às diversas demandas impostas pelo colonialismo: a subjugação política, a brutal exploração econômica, o desprezo das culturas autóctones africanas, o menosprezo às formas próprias de crenças e valores tradicionais, entre outros desastres. É em resposta, pois, a esse quadro, que o nacionalismo buscará elaborar respostas aos obstáculos colocados pelo colonialismo e erigir dos escombros desse mundo colonial cindido, os edificios das novas nações africanas e suas literaturas.

\section{O SISTEMA LITERÁRIO}

Adotar a formulação "sistema literário" significa esposar a perspectiva de Antonio Candido em seu Formação da literatura brasileira, ou seja, considerar o processo literário de países de passado colonial não como um processo "natural" ou como uma adaptação/ aclimatação da cultura dos colonizadores levada a efeito em outras latitudes, mas sim examinar os produtos literários a partir do desejo (e da ação) dos escritores de realizar uma literatura que os expressasse. Nessa senda, a correlação entre a série literária e a social define um método não apenas atinente à historiografia literária, mas também de leitura de textos.

É dessa forma que a lente formativa na focalização da história literária dos países de passado colonial permite pensar as relações entre autores, obras e públicos a partir de tensões como a de estar vinculado a um sistema não-local, mas expressar o nacional local, expressar o nacional a partir de formas consagradas nas metrópoles, ou seja, "a tensão entre o dado local (que se apresenta como substância da expressão) e os moldes herdados da tradição européia (que se apresentam como forma da expressão)". (CANDIDO, 1979, p. 30), ou 
ainda a necessidade de criação/ampliação do público, para citar alguns das mais importantes questões que a abordagem propicia.

Sob essa perspectiva, o projeto estético de construção de uma literatura própria converge com o projeto ideológico, como nos lembra Glissant:

Chamo de literatura nacional esta urgência para cada um de nomear-se diante do mundo, isto é, esta necessidade de não desaparecer da cena do mundo e de contribuir, ao contrário, à sua ampliação.

A produção literária que participa de tal consciência coletiva em busca de si mesma não é apenas exaltação da comunidade mas também reflexão sobre (e preocupação de ) sua expressão específica. O discurso não se contenta em dizer, mas exprime ao mesmo tempo a razão pela qual ele diz desta maneira e não de outra. (1981, p. 192)

A consolidação dos sistemas literários dos países africanos de língua oficial portuguesa é bastante recente, pois somente a partir do segundo quartel do século XX assistimos à articulação entre autor, obra e público, como um sistema orgânico, em que os aspectos de produção, recepção e tradição integraram-se em uma tríade dinâmica e situada historicamente.

Nesse momento aumentam decisivamente as pressões sobre os colonizados sobretudo em razão da maior lucratividade exigida das colônias dada a procura de produtos tropicais no mercado mundial, o que redundou em maior afluxo de metropolitanos aos territórios coloniais e suas conseqüências: a mudança das cidades, onde bairros inteiros foram destruídos para que uma nova população fosse ali alocada ou a ocupação das terras férteis que pertenciam aos africanos. Esse fluxo migratório é também incentivado pela propaganda na metrópole:

As colónias das revistas, manuais e dos romances a partir pelo menos dos anos 30 prometiam não apenas fortuna, mas também aventura e, sobretudo, um estilo de vida, que implicava uísque ou gin no fim da tarde - algo muito distante do trabalho de um camponês. (THOMAZ, 2008, p. 186) 
Como se pode aquilatar, a literatura não fica alheia ao esforço propagandístico de Portugal, e a criação do Concurso de Literatura Colonial da Agência Geral das Colônias ${ }^{6}$, servirá como incentivo a um grande número de textos de ficção em que se reafirmam as qualidades dos heróis brancos, a inferioridade e animalização dos negros e, portanto, a necessidade da "missão civilizatória" portuguesa nos territórios africanos. São textos populares - como o comprovam a quantidade de títulos editados e a rapidez com que se esgotaram grande número das edições - que exaltam a "portugalidade" e tornam o espaço africano apenas um cenário exótico, composto pela selva, animais perigosos e ... "os pretos". Em razão da sua estreita vinculação ao colonialismo, essa literatura acabou por ser transformada em paradigma do bem escrever nas então colônias portuguesas e, dessa forma, impôs-se como modelo tecnoformal naqueles territórios.

Será esse modelo, principalmente, que sofrerá a rejeição dos produtores africanos quando elaborarem os seus textos visando à construção de uma literatura nacional. Não se pode, todavia, falar de uma negação in totum da Literatura Portuguesa, já que, por exemplo, houve um produtivo diálogo dos autores angolanos dos anos $1950 \mathrm{com}$ a literatura neorrealista portuguesa. Ocorreu, antes, o rechaçar de toda uma linha de textos em que a visão do império português se consubstanciava.

Quando nos referimos aos países africanos de lingua portuguesa há três sistemas literários que ultrapassaram os "momentos iniciais" de formação, e encontram-se hoje plenamente consolidados: Angola, Cabo Verde e Moçambique. Serão esses, os três sistemas literários sobre os quais nos debruçaremos com mais vagar.

\section{ANGOLA}

6 Alberto Oliveira Pinto nos lembra que o concurso foi criado em 1926 e teria existência até 1951, sendo substituído em 1954 por quatro prêmios literários organizados igualmente por iniciativa da Agência Geral das Colônias, que viriam a durar até 1974. (PINTO, 2002, p. 191) 
Em Angola a constituição de uma literatura nacional consolidou-se nos fins dos anos 1940, mais precisamente em 1948, graças ao Movimento dos Novos Intelectuais de Angola, sob o lema de "Vamos descobrir Angola!", e os seus esforços (entre os quais a publicação da Antologia dos novos poetas de Angola - 1950 e da revista Mensagem Voz dos Naturais de Angola) que se consolida o sistema literário angolano.

O Movimento dos Novos Intelectuais, integrado, entre outros, por Viriato da Cruz e Antonio Jacinto, propunha-se a uma redescoberta de seu país e a uma modernização cultural sem alijar a cultura tradicional, ao mesmo tempo em que a sua produção visava a uma produção para o colonizado. Os integrantes do movimento

sabiam muito bem o que fora o movimento modernista brasileiro de 1922. Até eles havia chegado, nítido, o 'grito do Ipiranga' das artes e letras brasileiras, e a lição dos seus escritores mais representativos, em especial de Jorge de Lima, Ribeiro Couto, Manuel Bandeira, Lins do Rego e Jorge Amado, foi bem assimilada. (ERVERDOSA, 1978, p. 84)

Para os jovens do Movimento que iria definir os rumos da literatura angolana, a leitura de autores do modernismo brasileiro abriu caminhos, apresentando propostas estéticas e questões que eles próprios se colocavam. Opondo-se vivamente à padronização e aos modelos ditados pela ordem colonial, a valorização de elementos angolanos apontava para uma possibilidade de trazer à cena literária e não só - grande parte da sociedade angolana, segregada pelo colonialismo. Ao mesmo tempo, esses moços consideravam imprescindivel uma aposta na modernidade, pois isso significava não só estar no compasso do que se fazia no mundo, como também uma ruptura com o colonialismo tardio e prolongado.

Em razão disso, tornou-se necessário estabelecer o diálogo com outro universo cultural, que não o estreito mundo colonial e salazarista e a interlocução escolhida foi a produção cultural brasileira, o que, em 
última instância, propiciou a dinamização das reflexões sobre os caminhos da sua própria produção literária.

O Modernismo brasileiro, com o seu caráter de ruptura em 1922 mas, principalmente, o projeto ideológico de 1930, apresentava, para os angolanos as credenciais fundamentais para o diálogo.

Sob esse aspecto, conferência realizada por Mário de Andrade em 1942 à guisa de balanço do Modernismo (ANDRADE, 1974, p. 231-258), pode nos auxiliar a traçar algumas das convergências existentes entre $o$ programa dos brasileiros de 1922 e o dos angolanos de 1948. Recordese que naquele texto Mário de Andrade define o Modernismo como "uma ruptura, foi um abandono de princípios e de técnicas conseqüentes, foi uma revolta contra o que era a Inteligência nacional” (p. 240), aspecto esse foi percebido pelos Novos Intelectuais de Angola e assimilado, não apenas no que se refere ao aspecto formal da poesia, mas também de novos temas que freqüentariam o repertório poético angolano.

A essa luz, verifica-se que o rompimento com os modelos metropolitanos (representantes da "inteligência oficial" naquele momento) e a procura de formas da oralidade popular, ou melhor dizendo, a integração da $\underline{\mathrm{voz}}$ do povo iletrado na letra dos textos produzidos, marca a ruptura. Um bom exemplo nos fornece um texto como "Makèzu" (Poemas, 1961), poema de Viriato da Cruz, em que já no titulo há uma referência não apenas à fala popular (em quimbundo e não em português, como a demarcar territórios), como também a contraposição entre os velhos tempos e a modernização dos costumes.

\section{MAKÈZU7}

- "Kuakiê!... Makèzu, Maklèzu..."

O pregão da avó Ximinha

\footnotetext{
7 Makezu: desjejum tradicional, composto de noz de cola, também conhecido como obi (fruto das plantas pertencentes ao género Cole da subfamília Sterculioideae) e gengibre, que é mastigado.
} 
É mesmo como os seus panos,

Já não tem a cor berrante

Que tinha nos outros anos

Avó Xima está velhinha

Mas de manhã, manhãzinha,

Pede licença ao reumático

E num passo nada prático

Rasga estradinhas na areia...

Lá vai para um cajueiro

Que se levanta altaneiro

No cruzeiro dos caminhos

Das gentes que vão p'ra Baixa ${ }^{8}$.

Nem criados, nem pedreiros

Nem alegres lavadeiras

Dessa nova geração

Das "venidas de alcatrão"

Ouvem o fraco pregão

Da velhinha quitandeira.

- "Kuakié!...Makèzù, Makèzù..."

- “Antão, véia, hoje nada?”

- "Nada, mano Filisberto...

Hoje os tempo tá mudado..."

- "Mas tá passá gente perto...

- Como é aqui tás fazendo isso?"

- Não sabe?! Todo esse povo

Pegô um costume novo

Qui diz qué civrização:

Come só pão com chouriço

8 Baixa: centro da cidade. No tempo colonial, habitado sobretudo pelos brancos. 
Ou toma café com pão...

E diz ainda pru cima,

(Hum... mbundo kène muxima... $)^{9}$

Qui o nosso bom makèzù

É pra veios como tu"

- "Eles não sabe o que diz...

- Pru qué qui vivi filiz

E tem cem ano eu e tu?

- "É pruquê nossas raiz

Tem força do makèzù..."

Com uma forte valorização do mundo das raízes que "têm força de makèzu", a partir da focalização empática de uma velha quitandeira que comercializa o "mata-bicho" ou desjejum tradicional composto de cola e gengibre, o texto elabora uma tensão entre tradição e ruptura, oral e escrito, entre o português padrão e o "pretoguês" (forma pejorativa com que o colonizador nomeava os desvios de linguagem do colonizado), entre a língua do colonizador e a do colonizado.

Dessa forma, este texto, publicado pela primeira vez nos anos 1960 e posteriormente musicado por Rui Mingas 10 instaura um outro dizer, que busca "as raízes", que metaforicamente no texto são dadas a partir do Makezu, explicitando assim o projeto estético e o projeto ideológico.

Recorrendo mais uma vez à citada palestra de Mário de Andrade, pode-se pensar que os três principios fundamentais que teriam presidido ao Modernismo brasileiro aludidos por Mário, mobilizaram os autores angolanos, na medida em que eles teria galvanizado os anseios da geração de artistas que procuravam novas formas de expressão de uma singularidade angolana: “o direito permanente à pesquisa estética;

\footnotetext{
${ }^{9}$ Mbundu kene muxima, do kimbundu : as pessoas não têm coração.

10 Martinho da Vila, no Brasil, gravou a música no disco 3.O-Turbinado ao vivo (SonyBMG, 1998).
} 
a atualização da inteligência artística brasileira e a estabilização de uma consciência criadora nacional." (ANDRADE, 1974, p. 242).

Como bem nos lembra Rita Chaves, a apropriação dos pressupostos de 1922 também ocorreu sob uma clave politica, na medida em que a estabilização da consciência nacional passava, necessariamente, pela autonomia politica:

Pressuposto para a concretização da autonomia sonhada, a estabilização da consciência nacional era uma espécie de condição para que a pátria se transformasse em nação. Por isso era preciso trabalhar as divisões internas, investindo na consolidação de um projeto que não ignorasse as diferenças inerentes a um solo onde a diversidade de etnias, linguas e tradições compunha um intrincado mosaico cultural. (CHAVES, 1999, p. 48)

A essa luz, deve-se lembrar que se a leitura do Modernismo brasileiro realizada em Angola foi estética, sem dúvida ela rapidamente se transformaria em política, fazendo com que o programa levado a efeito pelos autores angolanos tomasse uma forte dimensão éticoestética, já que a mesma, conforme nos lembra Benjamin Abdala Júnior

(...) esteve ligada a uma conscientização político-social. Tratava-se nesses países, como ocorrera no Brasil, de prestigiar um nivel de fala de identificação nacional. Os registros múltiplos desses niveis apontavam para situações socioculturais diversas, tanto no plano de cada cidade (com as divisões sociais internas) como no plano das várias regiões de cada país. (ABDALA JÚNIOR, 1989, p. 73)

Sob esse particular, avulta na geração angolana de 1950, um elemento imprescindivel na modernidade literária: a presença da utopia. $\mathrm{E}$ aqui demarcam-se as diferenças entre os "modernos" brasileiros de 1922 e os "novos angolanos” da geração de 50, pois nestes últimos ela será presentificada, não apenas nas intenções, mas também nos gestos. Assim, com uma “consciência crítica do subdesenvolvimento", para utilizar a excelente expressão de Antonio Candido, os autores angolanos consolidaram o seu sistema literário e, pouco tempo depois, lutariam, na guerra de libertação, contra o colonialismo. A luta seria árdua e a utopia extremamente necessária a fim de manter acesa a chama da 
"sagrada esperança" até a chegada da independência, a 11 de novembro de 1975.

MOÇAMBIQUE

Diferentemente de Angola, não temos em Moçambique um movimento ou um momento específico que possamos identificar como de consolidação de sua literatura. Há um processo cujos inícios podemos situar no primeiro quartel do século XX a partir da fundação do jornal O Brado Africano (1918), no qual foram veiculados textos dos irmãos Albasini e do poeta Rui de Noronha, por exemplo, passando pela coletânea Poesia de Moçambique, publicada pela Casa dos Estudantes do Império, em Portugal (1951) e pelo único número do jornal Msaho (1952) - infelizmente sem continuidade por obra e graça da censura - e, nos anos 1960, a publicação do livro de contos de Luís Bernardo Honwana Nós matamos o cão tinhoso (1964). É um largo arco temporal que inclui nomes como os de Fonseca Amaral, Orlando Mendes, Noêmia de Sousa e o poeta José Craveirinha, para citar alguns deles.

O que se pode afirmar é que a década de 1950 é especial para a literatura de Moçambique e, sob esse aspecto, pode-se afirmar que o Modernismo brasileiro foi também importante para os autores do Índico.

Não se pode deixar à margem um autor que inicia sua trajetória artística entre nós em 1931 com um romance, O país do Carnaval, e que se tornou referência obrigatória para toda uma geração de moçambicanos que contribuíram efetivamente para a consolidação da literatura de seu país. Trata-se de Jorge Amado, o qual foi lido não só pelos moçambicanos, como por todos os africanos dos países de lingua portuguesa, que unanimemente indicam o papel seminal da ficção do autor baiano na consolidação de seus sistemas literários.

No que tange à Moçambique, dentre os autores tributários de sua literatura, vale citar Noemia de Souza, de cujo "Poema a Jorge Amado" foi transcrita uma estrofe como epígrafe deste texto e a partir da qual é 
possivel aquilatar como literatura e postura ideológica convergem, já que tanto a intertextualidade remete ao Capitães da areia, como o último verso transcrito remete ao militante do partido comunista.

É no entanto, José Craveirinha, o poeta maior de Moçambique, que em entrevista em 1998 afirma:

Eu devia ter nascido no Brasil. Porque o Brasil teve uma influência muito grande na população suburbana daqui, uma influência desde o futebol, eu joguei a bola com jogadores brasileiros, como, por exemplo, o Fausto, o Leônidas da Silva, inventor da bicicleta. (...)

Então quando chegou o Jorge Amado, estávamos em casa. Jorge Amado marcou-nos muito por causa daquela maneira de expor as histórias. E muitas situações existiam aqui. Ele tinha aqui um público. Havia aqui a polícia política, a PIDE. Quando eles fizeram uma invasão à casa, puseram-se a revistar tudo e levaram o que quiseram levar. Ainda me lembro, Levaram uma mala e carregaram os livros, meus livros. Levaram os livros e a mala até hoje como reféns politicos. Depois de eles irem-se embora, é que minha mulher disse: ' $\mathrm{E} o$ Jorge Amado? Onde estava o Jorge Amado?' Nessa altura, já estavam atrás do Jorge Amado. (CHAVES, 2005, p. 157)

Trata-se aqui, a partir da referência a uma maneira especial de o autor brasileiro "expor as histórias", do reconhecimento de um dos maiores trunfos da literatura de Jorge Amado, qual seja, a sua capacidade de efabulação. Sem dúvida, Jorge Amado é um extraordinário contador de histórias que trouxe à cena da literatura brasileira, como protagonista, o negro e um imaginário africano como o panteão ioruba, por exemplo. Além disso, a linguagem de seus textos aproxima-se da oralidade e, sob esse aspecto, acaba por constituir uma contraposição a uma literatura bacharelesca ou, em outras palavras, aspira a tornar a escrita menos aristocrática e fazê-la compartilhada por um maior grupo de leitores. Esses aspectos, rapidamente elencados, remetem a preocupações e questões que dominavam os autores moçambicanos assim como escritores de outros países de lingua portuguesa. 
Veja-se, a respeito, como Mia Couto ${ }^{11}$ em texto iluminado referese ao papel exercido por Jorge Amado na consolidação da literatura realizada em seu país:

Eu venho de muito longe e trago aquilo que eu acredito ser uma mensagem partilhada pelos meus colegas escritores de Angola, Moçambique, Cabo Verde, Guiné Bissau e São Tomé e Príncipe. A mensagem é a seguinte: Jorge Amado foi o escritor que maior influência teve na gênese da literatura dos países africanos que falam português.

(...)

Nas décadas de 50, 60 e 70, os livros de Jorge cruzaram o Atlântico e causaram um impacto extraordinário no nosso imaginário coletivo. É preciso dizer que o escritor baiano não viajava sozinho: com ele chegavam Manuel Bandeira, Lins do Rego, Jorge de Lima, Erico Veríssimo, Rachel de Queiroz, Drummond de Andrade, João Cabral Melo e Neto e tantos, tantos outros.

(...)

$\mathrm{Na}$ altura, nós carecíamos de um português sem Portugal, de um idioma que, sendo do Outro, nos ajudasse a encontrar uma identidade própria. Até se dar o encontro com o português brasileiro, nós falávamos uma língua que não nos falava. E ter uma língua assim, apenas por metade, é um outro modo de viver calado. Jorge Amado e os brasileiros nos devolviam a fala, num outro português, mais açucarado, mais dançável, mais a jeito de ser nosso.

Ao afirmar a singularidade brasileira e ao denunciar as desigualdades locais situando-as em um movimento mais amplo, Jorge Amado agiu como um catalizador para os escritores africanos que, a partir de sua literatura, trilharam os caminhos da liberdade criativa e nacional.

\section{CABO VERDE}

É possível, no que se refere à literatura de Cabo Verde, estabelecer um momento específico de sistematização de seu sistema literário. Ainda que haja manifestações literárias interessantes, como o romance $O$ escravo sobre o qual falaremos brevemente, é a Revista

11 Palestra proferida pelo escritor moçambicano em homenagem a Jorge Amado ( São Paulo, 25 de março de 2008). 
Claridade que marcará um movimento de consolidação da literatura do arquipélago.

O motivo de enfatizarmos o romance escrito por Evaristo de Almeida, no século XIX prende-se à maneira como nesse texto ocorre a referência à estiagem, já que em suas páginas iniciais apresenta-se o belo jardim da protagonista, não deixando de referenciar também o viçoso pomar de sua casa. Cria-se, destarte, não o espaço inóspito que se encontra em obras posteriores da literatura caboverdiana, mas sim um ambiente fresco em que a bela mestiça Maria, a protagonista, se move.

Ora, se há uma diferenciação brutal entre a ambientação amena entre um texto dos fins do século XIX e um grupo considerável de textos em prosa que veiculam o inferno da seca, nos inícios do século seguinte, podemos pensar que há uma escolha deliberada em apresentar uma outra faceta da realidade que seja menos florida que aquela veiculada no romance de Almeida ou, para lembrarmos Antonio Candido, no grupo de textos pós-Claridade encontrariamos a expressão de uma "consciência do subdesenvolvimento", a partir da qual os autores voltaram-se "contra as classes dominantes, vendo na degradação do homem uma conseqüência da espoliação econômica e não do seu destino individual" (CANDIDO, 1989, p. 160).

Segundo essa perspectiva, é a geração de Claridade que inicia uma tradição em que os temas e imagens atinentes à seca e à tensão "ter de ir/querendo ficar" se constituem em lugar comum dos textos que assegura uma tradição. Não nos antecipemos, todavia.

Um pouco de história - os primeiros passos

Apesar da existência de manifestações literárias no século XIX, como o romance $O$ escravo (1856), acima referido, ou Amores d'uma creola, de Antonio de Arteaga (1899) pode-se situar na década de 1930 
a consolidação do sistema literário caboverdiano. A partir da atividade de jovens autores, instaura-se uma "continuidade literária, - espécie de transmissão da tocha entre corredores, que assegura no tempo o movimento conjunto, definindo os lineamentos de um todo" (CANDIDO, 1993, p.24 ) ou seja, o sistema literário está consolidado.

O caminho, no entanto, foi preparado por produções não muito distantes no tempo e nos objetivos. Lembre-se, por exemplo, Eugénio Tavares $^{12}$ que pode ser tomado como um precursor da Claridade $^{13}$, na medida em que defendeu a língua e a escrita do crioulo caboverdiano, escrevendo ele próprio em crioulo, ao mesmo tempo em que procurava retratar situações sociais degradantes provocadas pelo regime colonial, como forma de denunciar as condições da população.

Se Eugênio Tavares pode ser considerado como precursor da consolidação do sistema literário de Cabo Verde, não menos importante para a "tomada de consciência" inicial dos autores caboverdianos é a publicação, em 1935, em São Vicente, do livro de Jorge Barbosa intitulado Arquipélagos, que, reconhecidamente, marca o nascimento de uma poesia moderna, de/em Cabo Verde de maneira que temas, visão crítica da situação do Arquipélago e uma linguagem singular apontam para a mesma direção de produções que serão veiculados pouco tempo depois em uma revista editada na cidade de Mindelo, na mesma ilha de São Vicente.

Claridade

12 Eugénio Tavares (1821-1930) nasceu na Brava (Cabo Verde). Emigrou para os Estados Unidos da América, vítima de perseguição política pelo poder colonial Autodidata, funcionário publico, jornalista e polemista. Dramaturgo, ficcionista e poeta, autor de inúmeras mornas.Escreveu Mornas, cantigas crioulas. (1932)

13 Merece aqui referenciar Amilcar Cabral: "Alguns sonetos de Januário Leite, composições de E. Tavares, esta ou aquela obra de J. Lopes e P. Cardoso, são - há que reconhecê-lo - de valor incontestável. Pode-se mesmo afirmar que em E. Tavares (ao cantar o ambiente bravense) e P. Cardoso (ao traduzir, do crioulo, quadras populares do Fogo) encontra-se já algo do que, mais tarde, se tornaria realidade nos Poetas da nova geração: uma comunhão íntima entre o Poeta e o seu mundo." (CABRAL, 1976, p. 26) 
Ainda que o livro de poemas de Jorge Barbosa seja marco incontornável na formação do sistema literário de Cabo Verde, ganha relevo a primeira atividade intelectual coletiva das Ilhas: a revista Claridade, cujo número inicial foi publicado em $1936^{14}$.

Como gesto inaugural de uma literatura que procurava afirmar a sua nacionalidade, o ideário da publicação vinculava-se principalmente à afirmação da caboverdianidade, isto é, a redescoberta da realidade social e psicológica do Arquipélago, tarefa que se apresentava como principal aos seus idealizadores, em função da "amnésia cultural" imposta pelo colonialismo. É um momento em que haveria por parte dos intelectuais uma consciência do atraso econômico e social do arquipélago a qual, segundo nos ensina Antonio Candido, "funciona com presciência e depois consciência da crise, motivando $\mathrm{O}$ documentário e, com o sentimento de urgência, o empenho político" (CANDIDO, 1989, p. 158). Nesse sentido, os “claridosos" utilizam a expressão "fincar os pés na terra" como expressão de seu empenho estético e político de escrever Cabo Verde.

E para realizar tal projeto, a literatura brasileira é parte importante das referências dos claridosos, como afirma, Baltazar Lopes, um dos colaboradores e idealizadores de Claridade:

Ora, aconteceu que por aquelas alturas nos caíram nas mãos fraternalmente juntas em sistema de empréstimo, alguns livros que consideramos essenciais "pro domo nostra". Na ficção, o José Lins do Rego do Menino de engenho e do Banguê, o Jorge Amado do Jubiabá e do Mar morto, o Amado Fontes de Os Corumbas, o Marques Rebelo do Caso de mentira, que conhecemos por Ribeiro Couto; em poesia foi um "alumbramento" a "Evocação do Recife", de Manuel Bandeira (...) (LOPES, apud FERREIRA, 1988, p. 85, vol. I)

\footnotetext{
${ }^{14}$ Foram publicados nove números da revista entre 1936 e 1960 (Mindelo, Ilha de São Vicente): 1936 - dois números; 1937 - um número; 1947 - dois números; 1948, 1949, 1958 e 1960 - um número em cada um destes anos. Entre outros, contam-se os seguintes colaboradores da publicação: Aguinaldo Brito Fonseca, Antonio Gonçalves, Arnaldo França, Baltazar Lopes, Corsino Fortes, Félix Monteiro, Gabriel Mariano, Jorge Barbosa, Manuel Lopes, Onésimo Silveira, Osvaldo Alcântara, Ovídio Martins, Terêncio Anahory e Xavier Cruz.
} 
Para os jovens do Movimento que iria definir os rumos da literatura caboverdiana, a leitura de autores do Modernismo brasileiro abriu caminhos, apresentando propostas estéticas e algumas respostas a questões que eles próprios se colocavam.

Conforme afirma Simone Caputo Gomes,

Ao assumir a afinidade com o Brasil e sua cultura mestiça e autônoma, os escritores claridosos - em processo de emergência da consciência cultural e nacional (...) evidenciaram a sua determinação em refletir-se em (e por meio de) outros espelhos, mais próximos, porque detentores de um itinerário histórico igualmente colonizado. (GOMES, 2008, p. 112),

A notar, entretanto, que dentre os textos e autores citados por Lopes apenas Bandeira marcou presença nas hostes do primeiro modernismo brasileiro - e mesmo assim, como veremos, o texto citado tem uma outra ligação que não passa necessariamente pelos moços iconoclastas de São Paulo que realizaram a Semana de Arte Moderna de 1922. Os demais (José Lins do Rego, Jorge Amado, Amado Fontes) estarão mais ligados a uma prosa regionalista do que necessariamente à Semana.

Vale dar relevo que, segundo entendemos, a referência brasileira dos "claridosos" tem uma especial vinculação ao Movimento Regionalista do Recife, comandado por Gilberto Freyre, o que indica um maior vinculo à questão localista e, portanto, uma afirmação mais incisiva da caboverdianidade ${ }^{15}$.

A figura de Gilberto Freyre, inclusive, não pode ser esquecida quando se fala desse momento no Arquipélago, já que suas teses, muito especialmente sobre uma sociedade mestiça nos trópicos, tiveram leitores ávidos nas Ilhas. Sob esse aspecto, há de referir também uma

\footnotetext{
15 Vale lembrar aqui as palavras de Ruben G. Oliven sobre o antagonismo de posições entre o Modernismo de 1922 e o Movimento Regionalista de Freyre: "O movimento de 1926 tem um sentido, de certa maneira, inverso ao de 1922. Trata-se de um movimento que não atualiza a cultura brasileira em relação ao exterior, mas que deseja, ao contrário, preservar não só a tradição em geral, mas o especificamente a de uma região economicamente atrasada." (OLIVEN, 2001, p. 60)
} 
outra leitura que, muito provavelmente, tenha também sido feita pelos moços de Claridade: o Livro do Nordeste, de 1925, organizado pelo sociólogo brasileiro como edição comemorativa do centenário do jornal Diário de Pernambuco e que congregava estudiosos de vários estados nordestinos, além da colaboração de Fidelino de Figueiredo, do norteamericano Francis Butler Simkins e do poeta Manuel Bandeira que, instado a colaborar com um poema no qual recordasse sua infância no Recife, estranhou a "encomenda", mas acabou por escrever "Evocação do Recife". Tratava-se de um volume que buscava reunir pensadores de geografia vária em um mesmo esforço de descobrir, mas sobretudo, de resgatar e articular um legado específico, particularizando assim uma região ou, nas palavras de Moacir dos Anjos indicava, uma procura de "mapear e demarcar, em diversas áreas temáticas, o especificamente nordestino; (...) e também de fixar a região como berço da nacionalidade brasileira”. (ANJOS, 2001)

Segundo nos parece, é esse mesmo esforço de dotar Cabo Verde de uma identidade e de especificidade nacional, a partir da escolha e articulação de imagens, canções e paisagens que podemos ver em Claridade. Dessa forma, os vários artigos que preenchem as páginas da publicação cumprem esse papel, como se pode ver, por exemplo, no número 1 da revista, que abre com "dois motivos de finançom (batuques da ilha de Santiago)", passa por trechos do romance Chiquinho, para apresentar em seguida, em página e meia, reflexões de Manuel Lopes em "Tomada de vista" sobre o "ser caboverdiano" - o sentimento de pertença ao Arquipélago, sua psicologia e, especialmente, a sua singularidade. Com poucas diferenças, o mesmo esquema ocorre em outros números em que as análises sobre a língua elaboradas por Baltazar Lopes no artigo "Uma experiência românica nos trópicos (Revista $n^{\circ} 4$, de janeiro de 1947), ou ainda as reflexões de Teixeira de Sousa em "Sobrados, Lojas e Funcos - Contribuição para o estudo da evolução social da Ilha do Fogo" (Revista $n^{\circ} 8$, de maio de 1958) trazem a mesma busca de expor um legado particular, construir uma espécie de espelho sedutor em que os caboverdianos reconhecessem a sua face. 
Breves considerações finais

Nesse breve passeio pela história literária de três países africanos de língua portuguesa procurei examinar, a partir das questões e propostas de Antonio Candido, os "momentos decisivos" da formação da literatura de Angola, Moçambique e Cabo Verde, buscando verificar como os escritores e grupos de intelectuais dos três países exploraramalgumas vezes por veredas diversas - as potencialidades de afirmação do fazer literário em meio às estreitas brechas do sistema colonial.

Driblando as dificuldades do meio, lutando contra a censura, escolhendo caminhos e constituindo a tradição a partir de temas e linguagem próprios, os autores africanos construíram, a partir do diálogo com textos e autores do Brasil, literaturas capazes de exprimirem a sua singularidade.

\section{REFERÊNCIAS BIBLIOGRÁFICAS}

ABDALA JR. , Benjamin. Literatura, história e politica. São Paulo: Ática, 1989.

ANDRADE, Mário de. Aspectos da literatura brasileira. 5. ed. São Paulo: Martins, 1974.

ANDRADE, Mário Pinto de. Origens do nacionalismo africano. Lisboa: Ed. D. Quixote, 1998.

ANJOS, Moacir. Vinte notas sobre identidade cultural no nordeste do Brasil. Arte latina. Rio de Janeiro: Universidade Federal do Rio de Janeiro; Museu de Arte Moderna, nov. 2000.

BUARQUE DE HOLANDA, Sérgio. Raizes do Brasil. São Paulo: Cia das Letras, 1995.

CABRAL, Amilcar. Apontamentos sobre a poesia caboverdiana. In Obras escolhidas de Amílcar Cabral. Lisboa: Seara nova, 1976, p. 25-29 (vol. I). CANDIDO, Antonio. Educação pela noite e outros ensaios. São Paulo: Ática, 1989. 
CANDIDO, Antonio. Formação da literatura brasileira (momentos decisivos). Belo Horizonte; Rio de Janeiro: Itatiaia, 1993. (Reconquista do Brasil, 177).

CASTRO ALVES, A. Obra completa. Rio de Janeiro: Aguilar, 1960.

CHAVES, Rita. A formação do romance angolano. Entre intenções e gestos. Maputo; São Paulo: FBLP; Via Atlântica, 1999.

CHAVES, Rita. Angola e Moçambique: experiência colonial e territórios literários. Cotia: Ateliê, 2005.

ERVEDOSA, Carlos. Roteiro da literatura angolana. Luanda: União dos escritores angolanos, 1979 (Coleção 2K)

GLISSANT, Edouard. Le discours antillais . Paris: Seuils, 1981.

GOMES, Simone Caputo. Cabo Verde - Literatura em chão de cultura.

Cotia: Ateliê; Praia: Instituto da Biblioteca Nacional e do Livro, 2008.

GONZAGA, Tomás Antonio. In. Saúte, Nelson e SOPA, António. A Tha de Moçambique pela voz dos poetas. Lisboa: Edições 70, 1992.

GUERRA, Gregório de Matos. Obra Poética. 3.ed., Editora Record, Rio de Janeiro, 1992.

LAFETÁ, João Luís. 1930: A crítica e o modernismo. 2. ed. São Paulo: Duas Cidades; Ed. 34, 2000.

LARA FILHO, Ernesto. Crónicas da roda gigante. Lisboa: Afrontamento, 1990

LOPES, João. “Apontamentos”. Número 01 de Claridade. In FERREIRA, Manuel. Claridade: revista de arte e letras. Praia: Instituto caboverdiano do livro, 1989.

MAIA FERREIRA, José da Silva. Espontaneidades da minha alma. Às senhoras africanas. 3. ed. Luanda: União dos escritores angolanos. 1985.

MARGARIDO, Alfredo. Do nativismo ao "mundo que o mulato criou". Paris. Librairie Losuphone. Latitudes - Cahiers lusophones n. 16, dezembro de 2002, p. 56-62.

MEMMI, Albert. Retrato do colonizado precedido pelo retrato do colonizador. 2. ed. Rio de Janeiro: Paz e Terra, 1977.

MILOSZ, Czeslaw. "O historii polskiej literatury, wolnomyslicielach i masonach", texto mais tarde incluído no volume Prywatne obowiazki. 
Olsztyn: Pojezierze, 1990. In SOUZA, Marcelo Paiva de. Especulo. Madri, Revista digital, $\mathrm{n}^{\circ}$ 31, nov 2005, fev. 2006.

THOMAZ, Omar Ribeiro. Passagens para África. O Povoamento de Angola e Moçambique com Naturais da Metrópole. Análise Social, jan. 2008, n.186, p.183-190. 